\title{
Temporal trend of the homicide rate of Brazilian women
}

\author{
Tendência temporal da mortalidade por homicídio de mulheres em região brasileira
}

Karina Cardoso Meira ${ }^{1}$, Micaela Alves Rocha da $\operatorname{Costa}^{1}$, Ana Carolina da Costa Honório ${ }^{2}$, Taynãna César Simões ${ }^{3}$, Marcelo de Paula Camargo ${ }^{1}$, Glauber Weder dos Santos Silva ${ }^{1}$

Objective: to analyze the temporal trend of the homicide rate of women in the states of Northeastern Brazil. Methods: ecological study of temporal trend. Data were the 25,332 feminicide deaths recorded in the Mortality Information System. A temporal trend analysis was performed using negative binomial regression. Results: after the correction steps, there was an increase of approximately $17.0 \%$ in deaths, corresponding to the standardized average rate of 4.7/100,000 women. There were higher mortality rates in women in the second and third decades of life. Higher average rates per 100,000 women were observed in the states of Pernambuco (8.25) and Alagoas (6.32). An increase in mortality rates in all the states of the analyzed region, in the period verified was evidenced, with the exception of Sergipe. Conclusion: a high magnitude of feminicide rates and ascendant trends were observed in most states in the Northeast Region of Brazil.

Descriptors: Homicide; Women; Gender-Based Violence; Mortality; Ecological Studies.

Objetivo: analisar a tendência temporal das taxas de mortalidade por homicídio em mulheres, nos estados da Região Nordeste do Brasil. Métodos: estudo ecológico de tendência temporal. Os dados foram os 25.332 óbitos por feminicídio registrados no Sistema de Informação sobre Mortalidade. Realizou-se análise de tendência temporal, por meio da regressão binomial negativa. Resultados: após as etapas de correções, houve aumento de cerca de 17,0\% óbitos, correspondendo à taxa média padronizada de 4,7/100.000 mulheres. Observaramse maiores taxas de mortalidade em mulheres nas segunda e terceira décadas de vida. Maiores taxas médias por 100.000 mulheres foram observadas nos estados de Pernambuco $(8,25)$ e Alagoas $(6,32)$. Evidenciou-se aumento das taxas de mortalidade em todos os estados da região analisada, no período verificado, com exceção de Sergipe. Conclusão: evidenciaram-se alta magnitude das taxas de feminicídio e tendência ascendente na maioria dos estados da Região Nordeste do Brasil.

Descritores: Homicídio; Mulheres; Violência de Gênero; Mortalidade; Estudos Ecológicos.

\footnotetext{
${ }^{1}$ Universidade Federal do Rio Grande do Norte. Natal, RN, Brazil.

${ }^{2}$ Secretaria Municipal de Trabalho e Assistência Social da Prefeitura do Natal. Natal, RN, Brazil.

${ }^{3}$ Instituto de Pesquisa René Rachou, Fundação Oswaldo Cruz. Belo Horizonte, MG, Brazil. 


\section{Introduction}

The aggression against women has, in murder, the maximum expression of the violence of gender, being denominated feminicide. In this context, Latin America represents the region with the highest rates of feminicide in the world, being lower only in sub-Saharan Africa. The highest coefficients are observed in Brazil and Colombia, and the lowest in Chile and Mexico. In addition, in the period from 2001 to 2011, there was an ascendant trend in Brazil and Mexico, stationary in Chile and declining in Argentina and Colombia. In Brazil, this increase corresponded to 3.4\% per year $^{(1)}$.

It is estimated that in Brazil one in five women has been a victim of domestic violence ${ }^{(2)}$. In the last decade, 43,500 women were murdered, which is why the country ranks fifth in the world in the number of female homicides, with a rate of 4.5 per 100,000 wo$\operatorname{men}^{(1,3-7)}$. Due to this increase, the Brazilian State, in the last decade, has developed actions to combat violence against women. In this perspective, Law 11,340 of 2006, known as Maria da Penha, was created, which created mechanisms to curb violence against women, and Law 13,104 of 2015, which qualifies feminicide as a hideous crime, providing for more severe penalties.

Although there is a legal apparatus to repress this type of violence, there is a gap between legislation and practice, from the invisibility that crosses violence against women to the difficulty of articulating a resolute care network to combat this violence ${ }^{(1,8)}$. In this direction, a study comparing homicide mortality in women with and without prior notification of violence showed that $15.0 \%$ of women who died due to feminicide in Brazil in the period from 2011 to 2015 had reported domestic violence, indicating limitations and weaknesses of the care and attention network for women $^{(9-10)}$.

In this sense, health professionals, especially nursing professionals, often constitute the first therapeutic contact of women victims of domestic violence, and can provide them with qualified and integral assistance. In addition, notification of violence against women is one of the attributes of these professionals and contributes directly to the access to the protection network, as well as to the quality of information in information systems, which provide the necessary data for action planning and prevention of feminicide.

Therefore, because it is understood that feminicide is also a public health problem in $\operatorname{Brazil}^{[11-12)}$, with an increased risk of death from this cause in women living in the Northeast of Brazil in the first fifteen years of the 21 st century $^{(11)}$, this study aimed to analyze the temporal trend of homicide mortality rates in women in the states of the Northeast Region of Brazil.

\section{Methods}

It is an ecological study of the temporal trend, whose study population was composed of female deaths caused by feminicide, in the states of the Northeast Region of Brazil, from 1980 to 2014. Official mortality data from homicide were obtained from the Mortality Information System Brazilian Health Department, the most recent of which are from 2016. However, it was chosen to work with mortality rates in the same sizes, five-year averages, to avoid the occurrence of a new identifiability problem, due to artificial cyclical patterns, when periods and age ranges of different sizes are used in the estimation. For this reason, the data worked corresponded to the period mentioned above.

The death registers for aggression (homicides) were codes E960 to E969 and X85 to Y09, respectively, in the Ninth and Tenth International Classification of Diseases (ICD-9 and ICD-10). The age of death was grouped into four age groups: 10 to 19,20 to 39,40 to 59 and 60 and over.

When considering the high proportion of homicide records classified as an event whose intent is undetermined (hidden homicides), the deaths were corrected for each state in the Northeast Region, according to the proposed methodology ${ }^{(12)}$.

Correction of deaths due to homicides was carried out through proportional redistribution, second 
year, age group and state, in three stages ${ }^{(13)}$ : (1) the proportion of deaths due to aggression was calculated in relation to the total number of deaths by accidental and intentional external causes (self-inflicted, aggression and legal intervention); (2) the value obtained in the previous step was multiplied by the total number of deaths classified as events whose intention is indeterminate; (3) the result of the second stage was added to the total number of homicide deaths, as recorded by the Mortality Information System ${ }^{(13)}$, representing the death record for corrected aggression.

Once the death registration was corrective, the mortality rates were calculated, and population data were obtained from the Department of Informatics of the Unified Health System, based on the population census of the years 1980, 1991, 2000 and 2010, knowing that inter census projections for populations for July 1 of the inter census years were estimated by the Brazilian Institute of Geography and Statistics. In order to control the effect of the age structure, which is different among the studied regions, it was decided to standardize the average and annual mortality rates using the direct method, using the female population of the 2010 Census as a standard population ${ }^{(11)}$. Next, the exploratory analysis of the temporal trend of corrected homicide mortality rates was performed using standard line graphs of the mortality coefficients, second year and state, after smoothing the historical series by triennial moving averages. It should be noted that rates were calculated per 100,000 women.

For descriptive analyzes, the proportion of deaths in the period from 1980 to 1995 (ICD-9) and 1996 to 2014 (ICD-10) was assessed, in relation to variables: the means by which the homicide was perpetrated and the place of death, and race/color for the period from 1996 to 2014, because prior to this period, this information was not included in the death certificate. To evaluate the presence of statistically significant differences between the categories of the variables under analysis, the chi-square test was used at the $5.0 \%$ level $(\mathrm{p} \leq 0.05)$.

The time trend analysis was performed in two stages: initially, the exploratory analysis was performed using the autocorrelation function and the Durbin-Watson test to evaluate the autocorrelation of the historical series. Once the temporal dependence of the data was confirmed, the temporal trend was analyzed by means of the negative binomial regression, since the data showed over-dispersion (greater than the mean variance) and, thus, the Poisson regression did not prove to be the most adequate method, even the response variable corresponding to the data coming from counting ${ }^{(13)}$.

It should be noted that the number of deaths expected for each year represented the dependent variable; and the centralized calendar year, the independent variable. In this analysis, it was decided to estimate weighted regression models, proportional to the population size, adding parameter known as offset that consisted of the logarithm of the population of each locality ${ }^{(11,13)}$, given by the following equation:

$$
\begin{aligned}
& y_{i} \sim \text { Negative Binomial }\left(\mu_{p}, \theta\right) \\
& \log \log \left(\mu_{i}\right)= \log \log \left(N_{i}\right)+\beta_{0}+\beta_{1}(t-E(t))+\epsilon_{i} \\
& \epsilon_{t} \sim \operatorname{Gamma}(\theta, \theta)
\end{aligned}
$$

Where $\mu$ represents the mean of the response variable per year (number of deaths) at the location i, $\theta$ the dispersion parameter, $\beta_{0}$ the intercept, $\beta_{1}$ the centralized time variable, $(\mathrm{t}-\mathrm{E}(\mathrm{t}))$ the time variable minus time average and $\epsilon \mathrm{i}$ the random error with gamma distribution. Analyzes were performed using the statistical package MASS, in software R, version 3.1.0, considering statistically significant values of $\mathrm{p} \leq 0.05^{(13)}$.

The trend was classified as stationary, decreasing or ascending, according to the Relative Risk value, calculated by the exponentiation of the regression coefficient $\left(\mathrm{e}^{\beta 1(\mathrm{t}-\mathrm{E}(\mathrm{t}))}\right)$ and its $95 \%$ Confidence Interval $(95 \% \mathrm{CI})$. The series are classified stationary, descending and ascending by the evaluation of Relative Risk and respective 95\% CI, namely: stationary, when the 95\% CI contains the value 1; descendant, when Relative Risk and 95\% CI contain values less than 1; and ascendant, when Relative Risk and 95\% CI presented values above $1^{(11,13)}$. 


\section{Results}

During the study period, there were 25,332 deaths due to feminicide, corresponding to the standardized average rate of 3.99 deaths per 100,000 women. After correction steps, there was an increase of approximately 29,644 (17.0\%), representing the standardized average rate of 4.7 deaths per 100,000 women. The states of the Northeast Region of Brazil that presented the highest percentage of increase in average mortality rates after corrections were Ceará (135.0\%), Alagoas (67.4\%) and Sergipe (38.5\%).

The highest average mortality rates per 100,000 women were found in the states of Pernambuco (8.25) and Alagoas (6.32), and the lowest in Piauí (2.25). It should be noted that, at the beginning of the historical series, the highest corrected homicide rates among women were observed in the states of Pernambuco, Alagoas and Ceará. However, there was a change in the temporal evolution of mortality by this group in the early 2000s, since there was a significant reduction in mortality rates in the state of Pernambuco, and at the end of the series, the state of Alagoas took the first place in the rates of homicide mortality. In the other states that presented the lowest magnitude of homicide mortality, there was an increase from the 2000s.

In the two periods under review, the main means by which the homicide was perpetrated was the firearm, this difference being statistically significant at the $5.0 \%$ level. It is also pointed out the increase in the proportion of deaths by this means, when comparing the periods of 1980-1995 and 1996 to 2014. Regarding the place of occurrence, in the first period under analysis, there was no statistically significant difference between the deaths occurring in public roads and the other localities $(\mathrm{p}=0.100)$. However, in the following period, there was an increase in feminicide on public roads compared to other sites $(33.3 \%$, $\mathrm{p}=0.030$ ). In this context, it is evident the high proportion of deaths that occurred in women of race/color colored, in the period from 1996 to 2014 (Table 1).
Table 1 - Proportion of deaths, according to the means by which the homicide was perpetrated, place of occurrence and race/color

\begin{tabular}{|c|c|c|c|c|}
\hline \multirow{2}{*}{ Variables } & \multicolumn{2}{|l|}{ Period (\%) } & \multicolumn{2}{|l|}{ Period (\%) } \\
\hline & 1980 a 1995 & $\mathbf{p}^{*}$ & 1996 a 2014 & $\mathbf{p}^{*}$ \\
\hline Medium perpetrated & & $<0.001$ & & 0.001 \\
\hline Fire gun & 43.1 & & 56.7 & \\
\hline $\begin{array}{l}\text { Blunt and penetrating } \\
\text { object }\end{array}$ & 35.5 & & 31.2 & \\
\hline $\begin{array}{l}\text { Hanging or strangu- } \\
\text { lation }\end{array}$ & 2.7 & & 3.9 & \\
\hline Others & 18.6 & & 8.2 & \\
\hline Total & 100.0 & & 100.0 & \\
\hline Place of occurrence & & 0.100 & & 0.030 \\
\hline Residence & 28.3 & & 26.9 & \\
\hline Public highway & 24.9 & & 33.4 & \\
\hline Hospital & 27.1 & & 26.3 & \\
\hline Others & 19.7 & & 13.4 & \\
\hline Total & 100.0 & & 100.0 & \\
\hline Race/color ${ }^{\dagger}$ & & - & & 0.001 \\
\hline White & - & & 15.8 & \\
\hline Colored & - & & 83.7 & \\
\hline Yellow & - & & 0.3 & \\
\hline Indigenous & - & & 0.3 & \\
\hline Total & - & & 100.0 & \\
\hline
\end{tabular}

The historical series of homicide mortality in women, in the states of the Northeast Region of Brazil, presented an ascendant trend, with the exception of the state of Sergipe that presented stationarity ( $\mathrm{RR}=1.002$, 95\% CI 0.98-1.01). Regarding the temporal evolution of the mortality coefficients according to age group, the states of Bahia, Ceará and Maranhão were outstanding, with ancestry in all age groups, and the state of Sergipe, with a stationary trend in all age groups (Table 2). 
Table 2 - Mortality rate trend (per 100,000 women) by homicides, by age group and states, after correction, 1980 to 2014

\begin{tabular}{|c|c|c|c|}
\hline Location & $\begin{array}{l}\text { Age group } \\
\text { (years) }\end{array}$ & $\begin{array}{l}\text { Relative Risk } \\
\text { (CI95\%) }\end{array}$ & Trend \\
\hline \multirow{4}{*}{ Alagoas } & 10 to 19 & $1.04(1.03-1.05)$ & Ascendant \\
\hline & 20 to 39 & $1.02(1.01-1.03)$ & Ascendant \\
\hline & 40 to 59 & 1.03 (1.01-1.07) & Ascendant \\
\hline & $\geq 60$ & $0.99(0.98-1.01)$ & Stationary \\
\hline \multirow{4}{*}{ Ceará } & 10 to 19 & $1.02(1.01-1.04)$ & Ascendant \\
\hline & 20 to 39 & $1.03(1.01-1.04)$ & Ascendant \\
\hline & 40 to 59 & $1.02(1.03-1.05)$ & Ascendant \\
\hline & $\geq 60$ & $1.02(1.01-1.04)$ & Ascendant \\
\hline \multirow{4}{*}{ Paraíba } & 10 to 19 & $1.02(1.01-1.07)$ & Ascendant \\
\hline & 20 to 39 & $1.03(1.01-1.04)$ & Ascendant \\
\hline & 40 to 59 & $1.01(0.99-1.01)$ & Stationary \\
\hline & $\geq 60$ & $1.01(0.98-1.05)$ & Stationary \\
\hline \multirow{4}{*}{ Piauí } & 10 to 19 & 1.07 (1.05-1.09) & Ascendant \\
\hline & 20 to 39 & $1.04(1.02-1.06)$ & Ascendant \\
\hline & 40 to 59 & $1.01(1.02-1.04)$ & Ascendant \\
\hline & $\geq 60$ & $0.99(0.97-1.02)$ & Stationary \\
\hline \multirow{4}{*}{ Sergipe } & 10 to 19 & $1.01(0.99-1.02)$ & Stationary \\
\hline & 20 to 39 & $1.01(0.97-1.01)$ & Stationary \\
\hline & 40 to 59 & $0.99(0.97-1.01)$ & Stationary \\
\hline & $\geq 60$ & $1.01(0.99-1.03)$ & Stationary \\
\hline \multirow{4}{*}{ Bahia } & 10 to 19 & 1.07 (1.06-1.08) & Ascendant \\
\hline & 20 to 39 & $1.05(1.04-1.06)$ & Ascendant \\
\hline & 40 to 59 & $1.02(1.03-1.06)$ & Ascendant \\
\hline & $\geq 60$ & $1.04(1.03-1.06)$ & Ascendant \\
\hline \multirow{4}{*}{ Maranhão } & 10 to 19 & $1.06(1.05-1.07)$ & Ascendant \\
\hline & 20 to 39 & $1.03(1.02-1.04)$ & Ascendant \\
\hline & 40 to 59 & $1.04(1.02-1.05)$ & Ascendant \\
\hline & $\geq 60$ & $1.02(1.01-1.04)$ & Ascendant \\
\hline \multirow{4}{*}{ Pernambuco } & 10 to 19 & $1.02(1.01-1.10)$ & Ascendant \\
\hline & 20 to 39 & $1.02(0.99-1.03)$ & Stationary \\
\hline & 40 to 59 & $0.95(0.94-0.98)$ & Descendant \\
\hline & $\geq 60$ & $0.98(0.97-1.01)$ & Stationary \\
\hline \multirow{4}{*}{$\begin{array}{l}\text { Rio Grande } \\
\text { Norte }\end{array}$} & 10 to 19 & $1.05(1.02-1.07)$ & Ascendant \\
\hline & 20 to 39 & $1.03(1.01-1.04)$ & Ascendant \\
\hline & 40 to 59 & $1.02(1.01-1.03)$ & Ascendant \\
\hline & $\geq 60$ & $1.01(0.98-1.03)$ & Stationary \\
\hline \multirow{4}{*}{ Northeast } & 10 to 19 & $0.97(0.96-0.98)$ & Descendant \\
\hline & 20 to 39 & $0.96(0.94-0.99)$ & Descendant \\
\hline & 40 to 59 & $0.93(0.92-0.98)$ & Descendant \\
\hline & $\geq 60$ & $1.01(1.003-1.07)$ & Ascendant \\
\hline
\end{tabular}

\section{Discussion}

The study presents limitations, one of them refers to the ecological design, which does not allow to test hypothesis in relation to the object of study, because it is aggregated data, that is, the relation between the exposure factor and the event may not occurring at the individual level. Thus, an association between an exposure and an event at the level of the population does not allow affirming that it is more present in those who experience feminicide. In addition, the quality of information systems information should be considered with caution. However, these allow to analyze the behavior of homicide mortality in women and, thus, to subsidize evaluation and planning in health and Public Security, regarding the assistance to women in situations of violence after the implementation of the Maria da Penha Law.

Another contrast of the present study refers to the quality of the death records for SIM/DATASUS homicides, due to the large proportion of deaths classified as events whose intention is undetermined (hidden homicides). In this sense, this research sought to minimize this problem, applying the correction technique ${ }^{(12)}$, producing more reliable death rates for homicides.

In this study, the highest average mortality rates were found in the states of Pernambuco and Alagoas. A similar result has been presented for male homicide mortality, in the Northeast Region of Brazil, in the process known as internalization of violence. Thus, it is argued that gender-based violence is more prevalent in places where there is a high incidence of interpersonal violence and perpetuates the policy of extermination in regions where non-democratic rule of law ${ }^{(14)}$.

Still, the highest mortality rates were found in the second and third decades of life. In addition, it was the younger age groups that presented a statistically significant increase in mortality, as observed in other investigations ${ }^{(8,11)}$. Deaths occurring during this phase of the life cycle promote a great socioeconomic 
impact, with great loss of potential life years, with intense physical and psychological suffering for the relatives of victims.

It is known that the factors associated with mortality in women and men are differentiated, with feminicide being the highest expression of gender violence. However, the murders in both genders have patriarchy as the background, since it associates man to manhood, the use of force and heteronormativity, and the privilege of exercising violent acts, as an expression of virility ${ }^{(15-16)}$. Thus, in places with high homicide rates in men, a high prevalence of domestic violence and incidence of feminicide is also observed ${ }^{(8,11)}$.

The results of the present study indicate a progressive increase in the mortality rate for homicides in women from the 1990s, in the states of Northeast Brazil, with an average rate of 5.37 deaths per 100,000 women. The magnitude of mortality is lower only in countries like El Salvador (8.9), Colombia (6.3), Guatemala (6.2), and the three countries that kill women the most because of gender issues ${ }^{(14)}$. It is also worth noting that the average mortality rate in the state of Pernambuco was similar to the average mortality rate in Guatemala, which kills women in the world, pointing to the severity of feminicide in the Northeast of Brazil and the urgency of measures prevention and control of this problem that affects all areas of life and social classes.

In this study and in other investigations, there was a higher proportion of deaths in colored women, with the main places of occurrence being the domicile and the public highway, with a significant increase in the prevalence of deaths occurring on the public highway. In relation to the medium by which the aggression was perpetrated, the most notable are the firearm and piercing or penetrating objects ${ }^{(8,11,17-18)}$.

It is important to note that in terms of feminicide, according to the racial cut, in Brazil, in all regions, a reduction in the mortality rate due to homicides in white women was observed. Conversely, in colored women, there was an ascendant trend in mortality due to this cause ${ }^{(14)}$. This reality can perhaps be explained by the fact that colored women live in greater proportions in places with great social vulnerability and lack of state protection, a condition that increases structural and gender violence. These are regions of high social vulnerability, with a strong presence of organized crime and drug trafficking and absence of the State, increasing structural violence and, thus, domestic violence ${ }^{(2,5,14,17)}$.

In this context, it is worth mentioning the increase in the proportion of deaths occurring on public roads in all Brazilian regions ${ }^{(11)}$, it is believed that many partners or former partners, because they know the routine of the victims, can perpetrate the aggression in the exit of home, work or school, and thus many women may be terminating abusive relationships, using the prerogatives of the Maria da Penha Act. However, they have not received the necessary protection from the State to prevent deaths $s^{(8,10-11,17-18)}$.

In support of the aforementioned hypothesis, the literature and the present study demonstrate that there was no reduction in feminicide rates in Brazilian regions after the Maria da Penha Law had been in force. The period from 2001 to 2011 showed a reduction in mortality in Brazil only in $2007^{(17)}$. And, after this year in Brazil, mortality rates from this cause showed an ascendant trend, which was confirmed by other studies in all Brazilian geographic regions ${ }^{(8,11,14,18)}$, with the exception of the Southeastern Region, which showed a stationary trend in the period from 1980 to $2014^{(11)}$.

Thus, it is necessary to intensify the number of shelters and women service stations, given that in 2012, Brazil had only 348 of these points of attention: 220 Reference Centers for Women's Care, 122 Support Centers in Police Stations common and only 72 shelters for more than 5,000 municipalities ${ }^{(18)}$. In addition, it is important to train health professionals, who have provided care based on traditional gender roles and assistance, focused on physical symptoms ${ }^{(19)}$, and on the judiciary and police officers, to better accommo- 
date victims, as well as comply with protection and punishment provided for by the Maria da Penha Law, thus providing a wide discussion on gender inequalities in our society, especially in the school environment, from pre-school to the university environment.

\section{Conclusion}

The present study sought to analyze the mortality rates because of feminicide in the states of Northeastern Brazil. Therefore, a high magnitude and ascendant temporal trend of mortality due to this cause was observed in the states of the Northeast Region of Brazil. The exposed scenario reinforces the importance of this aggravation to health as a Public Health problem in this region.

\section{Acknowledgments}

To the Coordenação de Aperfeiçoamento de Pessoal de Nível Superior, for the promotion of this research, Code of Financing: 001. To the Universidade Federal do Rio Grande do Norte, for the Scientific Initiation fellowships.

\section{Collaborations}

Meira KC, Costa MAR, Honório ACC, Simões TC and Camargo MP contributed with project design, data analysis and interpretation, article writing and critical review of relevant intellectual content. Silva GWS collaborated with data analysis and interpretation, article writing, critical review of the intellectual content and approval of the final version to be published.

\section{References}

1. Molinatti F, Acosta LD. Tendencias de la mortalidad por agresiones en mujeres de países seleccionados de América Latina, 2001-2011. Rev Panam Salud Pública [Internet]. 2015 [cited Jan. 15, 2019];37(4/5):279-86. Available from: http:// iris.paho.org/xmlui/handle/123456789/8043
2. Meneghel SN, Rosa BAR, Ceccon RF, Hirakata VN, Danilevicz IM. Femicides: a study in Brazilian state capital cities and large municipalities. Ciênc Saúde Coletiva. 2017; 22(9):2963-70. doi: http://dx.doi. org/10.1590/1413-81232017229.22732015

3. Costa MC, Lopes MJM, Soares JSF. Violence against rural women: gender and health actions. Esc Anna Nery. 2015; 19(1):162-8. doi: http://dx.doi. org/10.5935/1414-8145.20150022

4. Sorrentino R, Friedman SH, Hall R. Gender considerations in violence. Psychiatr Clin North Am. 2016; 39(4):701-10. doi: http://dx.doi. org/10.1016/j.psc.2016.07.002

5. Martins-Filho PRS, Mendes MLT, Reinheimer DM, Nascimento-Júnior EM, Vaez AC, Santos VS, et al. Femicide trends in Brazil: relationship between public interest and mortality rates. Arch Womens Ment Health. 2018; 21(5):579-82. doi: http:// dx.doi.org/10.1007/s00737-018-0842-1

6. Madureira $\mathrm{AB}$, Raimondo ML, Ferraz MIR, Marcovicz GV, Labronic LM, Mantovani MF. Profile of men who commit violence against women who are arrested in delicto flagrante: contributions to confronting the phenomenon. Esc Anna Nery. 2014; 18(4):600-6. doi: http://dx.doi. org/10.5935/1414-8145.20140085

7. Borges LM, Lodetti MB, Girardi JF. Spousal homicide: what do criminal cases say. Psicol Argumento. 2014; 32(79):197-208. doi: http:// dx.doi.org/10.7213/psicol..argum.32.s02.A018

8. Meneghel SN, Portella AP. Femicides: concepts, types and scenarios. Ciênc Saúde Coletiva. 2017; 22(9):3077-86. doi: http://dx.doi. org/10.1590/1413-81232017229.11412017

9. Albarran J. Referentes conceptuales sobre femicidio/feminicidio: su incorporación en la normativa jurídica Venezolana. Comunidad Salud [Internet]. 2015 [citado 2018 Nov. 24];13(2):1690-329. Disponível em: http://www.redalyc.org/articulo. oa?id=375743552010

10. Barufaldi LA, Souto RMCV, Correia RSB, Montenegro MMS, Pinto IV, Silva MMA, et al. Gender violence: a comparison of mortality from aggression against women who have and have not previously reported violence. Ciênc Saúde Coletiva. 2017; 22(9):2929-38. doi: http://dx.doi. org/10.1590/1413-81232017229.12712017 
11. Souza ER, Meira KC, Ribeiro AP, Santos J, Guimarães RM, Borges LF, et al. Homicides among women in the different Brazilian regions in the last 35 years: an analysis of age-period-birth cohort effects. Ciênc Saúde Coletiva. 2017; 22(9):294962. doi: http://dx.doi.org/10.1590/141381232017229.12392017

12. Garcia LP, Freitas LRS, Silva GDM, Hofelmann DA. Estimativas corrigidas de feminicídios no Brasil, 2009 a 2011. Rev Panam Salud Pública [Internet]. 2015 [cited 2018 Nov. 24];37(4/5):251-7. Available from: https://scielosp.org/pdf/ rpsp/2015.v37n4-5/251-257/pt

13. Antunes JLF, Cardoso MRA. Using time series analysis in epidemiological studies. Epidemiol Serv Saúde. 2015; 24(3):565-76. doi: http://dx.doi. org/10.5123/S1679-49742015000300024

14. Waiselfisz JJ. Mapa da Violência 2015: homicídio de mulheres no Brasil. Brasília: Flacso; 2015.

15. Peroya E, Reynolds SA. Women's police stations and intimate partner violence: evidence from Brazil. Soc Sci Med. 2017; 174(1):188-96. doi: https:// doi.org/10.1016/j.socscimed.2016.12.008
16. Bando DH, Lester D. An ecological study on suicide and homicide in Brazil. Cienc Saúde Coletiva. 2014; 19(4):1179-89. doi: http://dx.doi. org/10.1590/1413-81232014194.00472013

17. Meneghel SN, Margarites AF. Feminicide in Porto Alegre, Rio Grande do Sul State, Brazil: genderiniquities in dying. Cad Saúde Pública. 2017; 33(12):e00168516. doi: http://dx.doi. org/10.1590/0102-311X00168516

18. Garcia LP, Freitas LRS, Hofelmann DA. Impact of Maria da Penha Law on female mortality due to aggression in Brazil, 2001-2011. Epidemiol Serv Saúde. 2013; 22(3):383-94. doi: https://doi. org/10.5123/s1679-49742013000300003

19. Cortes LF, Arboit J, Padoin SMM, Paula CC. Evidence of health care offered to women in situations of violence. Rev Rene. 2015; 16(6):100615. doi: http://dx.doi.org/10.15253/21756783.2015000600019 